(RESEARCH ARTICLE)

\title{
Effect of auxin type on the total phenols synthesis and some enzymatic proteins activity in maize callus from seeds irradiated to gamma radiation
}

Kanga Ahou-Nadia ${ }^{1, *}$, Ayolie Koutoua ${ }^{1}$, Yapo Sopie Edwige Salomé ${ }^{1}$, N'guessan Affoué Rachelle ${ }^{1}$, Kouakou Tanoh Hilaire ${ }^{2}$ and Kouadio Yatty Justin ${ }^{1}$

${ }^{1}$ University Jean Lorougnon Guédé, UFR (Faculty) of Agroforestry, Laboratory for improving agricultural production, BP 150 Daloa, Côte d'Ivoire.

${ }^{2}$ University Nangui Abrogoua, UFR Natural Sciences, Laboratory of Biology and Improvement of Plant Productions, Abidjan, Côte d'Ivoire.

Publication history: Received on 19 April 2020; revised on 09 May 2020; accepted on 12 May 2020

Article DOI: https://doi.org/10.30574/wjarr.2020.6.2.0107

\begin{abstract}
Secondary metabolites of plants widely used in the medicinal and cosmetic industries, can be produced by tissue culture. In vitro production of these secondary metabolites is affected by various factors such as the type and concentration of phyto regulators. In this study, 2,4-dichlorophenoxyacetic acid (2,4-D) and 2-methoxy-3,6-dichlorobenzoic acid (Dicamba) effect on phenolic compounds synthesis as well as Phenylalanine ammonia lyase (PAL), tyrosine ammonia lyase (TAL), Polyphenoloxidase (PPO), peroxidase (POD), Catalase (CAT) and Ascorbate Peroxidase (APX) activities from root explants have been studied. The root explants come from the seeds in vitro germination of maize irradiated (200 and 300 grays) or not irradiated (control) with gamma radiation. The results obtained showed that the auxin type had a very highly significant effect $(\mathrm{p}<0.001)$ on all parameters studied. Callus induced on medium containing 2,4-D gave a higher content of phenolic compounds, PAL, TAL, PPO, POD, CAT and APX than callus induced on medium containing dicamba. The highest content of total phenols $(76.971 \mu \mathrm{mol} / \mathrm{g}$ fresh callus $)$ was obtained in callus from 300 grays. By cons, the contents of POD, PAL, TAL, CAT and APX $(4.034 ; 0.031 ; 0.145 ; 1315.596$ and $2461.714 \mathrm{mmol} / \mathrm{min} / \mathrm{g}$ fresh callus) were obtained in callus from 200 grays.
\end{abstract}

Keywords: Callus, 2, 4-D; Dicamba; Phenolic compounds; Enzymes; Gamma radiation; Maize.

\section{Introduction}

Maize (Zea mays L.) is an annual tropical herbaceous plant of the Poaceae family (grasses). It is a cereal cultivated under very varied conditions ranging from tropical to temperate climates. In the world, Maize is the first cereal $(41 \%)$ cultivated in terms of quantity and area, ahead of wheat $40 \%$ and rice $9 \%$ [2]. World maize production was 1.06 million tones with the United States as the main producer, followed by China and Brazil [8].

Africa maize production is estimated at more than 70 million tones for an area of 34 million hectares [10]. It is estimated that more than 300 million people in sub-Saharan Africa depend on maize as a source of food and livelihood. Maize makes up almost half of calorie and protein contributions in Eastern and Southern Africa, and a fifth in West Africa [10].

In Côte d'Ivoire, maize is the second most widely grown cereal after rice. It occupies a prominent place in agricultural activities, in human and animal nutrition [14]. Annual national maize production is approximately 654,738 tones, for a total area of 327,800 hectares. Its national consumption is estimated at 28.5 kilograms per inhabitant per year [5]. According to FAO production estimates and compared to the situation in neighboring countries, the Ivorian maize sector seems to experience relatively slow growth because its cultivation faces many problems. These problems are linked not only to land degradation but especially to climate change. Recent studies suggest that production of major products has

\footnotetext{
* Corresponding author: Kanga Ahou-Nadia
} 
declined since 1980 due to global warming [17]. It is estimated that, given current trends in global warming in subSaharan Africa, major cereal production could decline by up to $20 \%$ by century middle [30].

In addition, genetic degeneration of the varieties is combined with the constraints mentioned above to make the cultivation of this cereal more difficult. To this end, many solutions are sought around the world. These are mainly the fertilizers use and high-performance varieties most often introduced. Consequently, biotechnology has been developed in addition to conventional methods in order to achieve more effective improvement protocols for this cereal. Among the various regeneration systems, somatic embryogenesis is highly coveted because it regularly ensures high multiplication rates which can be maintained for a long time. The somatic embryogenesis system has been the method of choice for tissue culture, regeneration and processing of maize for over twenty years. Somatic embryogenesis plays an important role in the clone's propagation. In addition, this technique is highly coveted for genetic transformation [32]. Somatic embryogenesis involves the establishment of an explant in culture, callus proliferation and the somatic embryos initiation [36]. The phytohormones used in tissus culture are mainly auxins, cytokinins and gibberellins [4]. These hormones are really essential for carrying out tissus culture. In tissue culture, to induce calluses and somatic embryos, hormonal stress is essential [15] l. According to several authors, 2,4-D is the best auxin which induces the maximum embryogenic calluses [13, 20,1]. During callogenesis and embryogenic structures induction, there is an intense metabolism of biochemical compounds [18]. The chemical reactions that lead to synthesis or catabolism of these compounds are catalyzed by many enzymes. Gamma irradiation of seeds and hormones type appear to be important factors in stimulating biochemical and physiological processes [8]. This is why this present work aims to study the effect of auxin type on the phenolic compounds synthesis and some enzymatic proteins activities in calluses.

\section{Material and methods}

\subsection{Disinfection and maize seeds germination}

Under a laminar flow hood, the maize seeds irradiated (200 and 300 grays) and non-irradiated seeds were soaked in fungicide (18 $\mathrm{mL} / 15 \mathrm{~L}$ ) for $5 \mathrm{~min}$, in $70 \%$ alcohol for $3 \mathrm{~min}$ and in $3.6 \%$ active chlorine sodium hypochlorite with 3 drops of tween 20 for $40 \mathrm{~min}$. The seeds were rinsed 4 times with sterile distilled water for 5 minutes. Then, one seed per test tube containing sterile distilled water is put in the dark for $48 \mathrm{~h}$. After this imbibition time, the seeds whose radicles appear, were cultured in test tubes containing $15 \mathrm{ml}$ of germination medium. The test tubes containing the seeds were incubated in the dark for 2 days and then transferred to the culture room under a light for 5 days. Maize vitroplants obtained were used as an explant source.

\subsection{Germination medium and culture condition}

Murashige and Skoog (MS) medium [23], supplemented with sucrose (30 g/L), was used. The medium pH was adjusted to 5.8 with $\mathrm{NaOH}(1 \mathrm{~N})$ or $\mathrm{HCl}(1 \mathrm{~N})$ and then solidified with agar-agar $(6 \mathrm{~g} / \mathrm{L})$. The culture medium was sterilized in an autoclave (Sanoclav) for $20 \mathrm{~min}$ at $121^{\circ} \mathrm{C}$, under 1 bar pressure. In culture room, all cultures were maintained at $25 \pm$ $2{ }^{\circ} \mathrm{C}$ under a $16 \mathrm{~h} / 8 \mathrm{~h}$ light/dark photoperiod and at $70 \%$ relative humidity. The light intensity $\left(100 \mu \mathrm{E}^{-\mathrm{m}^{-2}} \cdot \mathrm{sec}^{-1}\right)$ was provided by warm-white fluorescent lamps.

\subsection{Callus induction}

For maize callus induction, two auxins types, 2,4 dichlorophenoxyacetic acid (2,4-D), and Dicamba at $2 \mathrm{mg} / \mathrm{L}$ each were supplemented in the callogenesis medium composed of MS medium supplemented with $30 \mathrm{~g} / \mathrm{L}$ of sucrose. So, the root explants were cut with a sterile scalpel and placed on the callus induction medium and then placed in culture room for 4 weeks. After three subcultures (4 weeks/ subcultures), the callus was used for the assays.

\subsection{Extraction and phenolic compounds determination}

\subsubsection{Extraction}

Phenolic compounds extraction was carried out according to method of [15]. $500 \mathrm{mg}$ callus sample from each treatment was placed in $10 \mathrm{~mL}$ of methanol $(96 \%)$. The mixture was then incubated in the dark for $10 \mathrm{~h}$ at $4{ }^{\circ} \mathrm{C}$. After centrifugation at $5000 \mathrm{rpm}$ during $10 \mathrm{~min}$, the supernatant obtained was filtered through a Millipore membrane $(0.45$ $\mu \mathrm{m})$ and formed the crude phenolic extract.

\subsubsection{Dosage}

Phenolic compounds dosage was carried out according to method of [32]. So, $0.5 \mathrm{~mL}$ of folin-ciocateu (5 N) reativ was added to $0.9 \mathrm{~mL}$ of distilled water. To this was added $0.1 \mathrm{ml}$ of phenolic extract. The mixture was stirred at ambient 
temperature, then $1.5 \mathrm{~mL}$ of sodium carbonate $(17 \%)$ and distilled water $(6 \mathrm{~mL})$ were added to solution. The solutions obtained were incubated for 30 minutes. The optical density is determined at $765 \mathrm{~nm}\left(\mathrm{OD}_{765}\right)$ using a spectrophotometer. The total phenols concentration is determined using a standard curve carried out with different concentrations of gallic acid solution $(200 \mu \mathrm{g} / \mathrm{mL})$.

\subsection{Extraction and enzymatic proteins determination}

The quantitative study of enzymes concerned three enzymes types what are phenylalanine- ammonia-lyase (PAL) and tyrosine ammonia-lyase (TAL) (biosynthesis enzymes of phenolic compounds); polyphenoloxidase (PPO) and peroxidase (POD) (degradation enzymes of phenolic compounds), catalase (CAT) and ascorbate peroxidase (APX) (antioxidant enzymes).

\subsubsection{Enzymatic proteins Extraction}

Enzymes extraction was carried out cold $\left(4^{\circ} \mathrm{C}\right)$ with $500 \mathrm{mg}$ of fresh callus crushed in $5 \mathrm{~mL}$ of phosphate buffer $(0.1 \mathrm{M})$ and $0.05 \mathrm{~g}$ of polyvinylpyrrolidone (PVP). During grinding, $0.1 \mathrm{~mL}$ of solution composed of $5 \%$ polyethylene glycol 6000 (PEG 6000), $0.25 \%$ sodium thiosulfate, $15 \%$ glycerol, $1 \mathrm{mM}$ EDTA, and $15 \mathrm{mM}$ mercaptoethanol, was added. After centrifugation, at $5000 \mathrm{rpm}$ during $20 \mathrm{~min}$, the supernatant obtained represents the crude enzyme extract.

\subsubsection{Enzymatic proteins dosage}

Polyphenoloxidases. The determination of Polyphenoloxidases (PPO) was carried out according to the method of Zhou et al. (2003). During the dosage, $3 \mathrm{ml}$ of reaction volume composed of $0.2 \mathrm{ml}$ of enzymatic extract, $1 \mathrm{ml}$ of pyrocatechol, and $1.8 \mathrm{ml}$ of phosphate citrate buffer $(0.1 \mathrm{M}, \mathrm{pH} 6.5)$ was used. The oxidation of pyrocatechol is determined using a spectrophotometer at $500 \mathrm{~nm}\left(\mathrm{OD}_{500}\right)$. The Polyphenoloxidases activities is expressed by considering that the molar extinction coefficient of the product formed is $1400 \mathrm{M}^{-1} \cdot \mathrm{cm}^{-1}$.

Peroxidase. The peroxidase (POD) activity was carried out according to method of Santimone (1973). During the dosage, $0.1 \mathrm{~mL}$ of enzyme extract was taken and put into test tubes. To this extract is added $2.9 \mathrm{~mL}$ of a solution composed of 10-2 M guaiacol and 10-2 M hydrogen peroxide (H2O2) (v/v). The reaction mixture was stirred and then incubated in dark during $10 \mathrm{~min}$. The oxidation of guaiacol is followed using a spectrophotometer at $470 \mathrm{~nm}\left(\mathrm{OD}_{470}\right)$. The peroxidase (POD) activity is expressed by considering that the molar extinction coefficient of the product formed is $26.6 \mathrm{mM}^{-1} . \mathrm{cm}^{-}$ 1.

Phenylalanine and tyrosine ammonia-lyases. The dosage was carried out according to method of Regnier (1994). $0.1 \mathrm{ml}$ of enzyme extract, $1 \mathrm{ml}$ of $0.1 \mathrm{M}$ phenylalanine for PAL or $0.1 \mathrm{M}$ tyrosine for TAL and $1.9 \mathrm{ml}$ of sodium borate buffer $(0.2$ $\mathrm{M})$ at $\mathrm{pH} 8.8$ were used for this dosage. The reaction mixture was incubated at ambient temperature during $30 \mathrm{~min}$ and the PAL and TAL activities were followed by spectrophotometer at $290 \mathrm{~nm}\left(\mathrm{OD}_{290}\right)$. This activity is proportional of cinnamic acid quantity formed. The PAL and TAL activities are expressed by considering that the molar extinction coefficient of cinnamic acid is $19600 \mathrm{M}^{-1} \mathrm{~cm}^{-1}$ and that of p-coumaric acid is $17600 \mathrm{M}^{-1} . \mathrm{cm}^{-1}$.

Peroxidase Ascorbate and catalase. The catalase and ascorbate peroxidase activities were determined according to the method of [32]. The ascorbate peroxidase determination was carried out with $3 \mathrm{ml}$ of reaction volume comprising 0.1 $\mathrm{mL}$ of enzymatic extract and $2.9 \mathrm{~mL}$ of ascorbic solution. The ascorbate peroxidase activity is monitored using a spectrophotometer at $290 \mathrm{~nm}\left(\mathrm{OD}_{290}\right)$. The dosage of catalase was carried out with the same reaction including $0.1 \mathrm{~mL}$ of enzymatic extract, $1 \mathrm{~mL}$ of $\mathrm{H}_{2} \mathrm{O}_{2}$, and $1.9 \mathrm{~mL}$ of Tris- $\mathrm{HCl}$ buffer. The catalase activity is followed with a spectrophotometer at $240 \mathrm{~nm}\left(\mathrm{OD}_{240}\right)$. The molar extinction coefficient of product formed is $0.0436 \mathrm{mM}^{-1} . \mathrm{cm}^{-1}$ for catalase and $2.8 \mathrm{mM}^{-1} \cdot \mathrm{cm}^{-1}$ for ascorbate peroxidase.

\subsection{Statistical analysis}

The data were statistically analyzed with STATISTICA software, version 7.1. Analysis of variation (ANOVA) was used to test statistical significance, and significant differences between the means were calculated using Tukey's HSD test at P $<0.05$.

\section{Results}

\subsection{Effect of auxin type on the phenolic compounds synthesis}

The results relating to effect of the auxin type on the phenolic compounds content in maize callus are reported in Table I. Analysis of results shows that the auxin type has a significant effect $(p<0.024)$ on the phenolic compounds content, 
whatever the irradiation dose. Indeed, calluses induced on medium containing 2,4-D contain more polyphenols (49,841 $\mu \mathrm{g} / \mathrm{g}$ fresh callus) than callus induced on Dicamba medium $(31,660 \mu \mathrm{g} / \mathrm{g}$ fresh callus). However, in the presence of 2,4$\mathrm{D}$, the highest content is obtained in callus from 300 grays $(76.971 \mu \mathrm{g} / \mathrm{g}$ fresh callus) and the lowest in the callus from control ( $33.643 \mu \mathrm{g} / \mathrm{g}$ fresh callus). In addition, the lowest content is obtained in Dicamba medium with control callus (27.526 $\mu \mathrm{g} / \mathrm{g}$ fresh callus).

Table 1 Effect of auxin type on the phenolic compound in callus

\begin{tabular}{lll}
\hline Irradiation dose & Auxin type & phenolic compounds $(\boldsymbol{\mu g} / \mathbf{g}$ fresh callus) \\
\hline Control & 2,4-D & $33,643 \pm 0,11 \mathrm{a}$ \\
& Dicamba & $27,526 \pm 0,11 \mathrm{~b}$ \\
200 grays & $2,4-\mathrm{D}$ & $38,910 \pm 0,52 \mathrm{a}$ \\
& Dicamba & $32,963 \pm 0,50 \mathrm{~b}$ \\
300 grays & 2,4-D & $76,971 \pm 2,87 \mathrm{a}$ \\
& Dicamba & $34,492 \pm 0,95 \mathrm{~b}$ \\
$\mathrm{P}$ & & 0.024 \\
$\mathrm{~F}$ & & 6,191 \\
\hline
\end{tabular}

\subsection{Effect of auxin type on enzymatic proteins in maize calluses}

The variation of Phenylalanine-ammonia-lyase (PAL), tyrosine ammonia-lyase (TAL), Polyphenoloxidase (PPO), peroxidase (POD), Catalase (CAT) and Ascorbate Peroxidase (APX) activities under the effect of auxin type in the calluses is recorded in Tables II and III.

Table 2 Effect of auxin type on the PPO, POD, PAL and TAL activities in maize callus

\begin{tabular}{|c|c|c|c|c|c|}
\hline \multirow[t]{2}{*}{ Dose } & \multirow{2}{*}{$\begin{array}{l}\text { Type of } \\
\text { auxin }\end{array}$} & \multicolumn{4}{|c|}{ Enzymatic activity (mmol/min/g fresh callus) } \\
\hline & & PPO & POD & PAL & TAL \\
\hline & 2,4-D & $0,805 \pm 0,003^{a}$ & $1,898 \pm 0,003^{a}$ & $0,022 \pm 0,001^{\mathrm{a}}$ & $0,135 \pm 0,001^{\mathrm{a}}$ \\
\hline Control & Dicamba & $0,548 \pm 0,003^{b}$ & $0,520 \pm 0,001^{b}$ & $0,010 \pm 0,001^{b}$ & $0,120 \pm 0,001^{b}$ \\
\hline \multirow[t]{2}{*}{200 grays } & $2,4-D$ & $0,788 \pm 0,003^{a}$ & $4,034 \pm 0,099^{a}$ & $0,031 \pm 0,001^{\mathrm{a}}$ & $0,145 \pm 0,002^{a}$ \\
\hline & Dicamba & $0,571 \pm 0,002^{b}$ & $2,003 \pm 0,017^{b}$ & $0,009 \pm 0,001^{b}$ & $0,133 \pm 0,001^{b}$ \\
\hline \multirow[t]{2}{*}{300 grays } & 2,4-D & $0,777 \pm 0,005^{\mathrm{a}}$ & $2,584 \pm 0,046^{a}$ & $0,024 \pm 0,001^{\mathrm{a}}$ & $0,145 \pm 0,001^{\mathrm{a}}$ \\
\hline & Dicamba & $0.542 \pm 0,005^{b}$ & $0,635 \pm 0,012^{b}$ & $0,009 \pm 0,001^{b}$ & $0,116 \pm 0,001^{b}$ \\
\hline $\mathrm{P}$ & & 0.001 & 0.001 & 0.001 & 0.001 \\
\hline $\mathrm{F}$ & & 549,14 & 19,553 & 62,302 & 30,630 \\
\hline
\end{tabular}

The values followed by the same letter are not significantly different (Tukey's test at $5 \%$ ).

PPO: polyphenoloxidase ; POD: Peroxidase ; PAL : Phenylalanine-ammonia-lyase ; TAL : Tyrosine ammonia-lyase

The tables Analysis shows that the auxin type exerts a very significant influence $(\mathrm{p}<0.001)$ on the enzymatic activities studied (all doses combined). Indeed, the activity of PPO, POD, PAL, TAL, catalase and ascorbate peroxidase is higher in the calluses induced on 2,4-D medium (respectively $0.79 ; 2.84 ; 0.02 ; 0.14 ; 1141.9$ and $2346.3 \mathrm{mmol} / \mathrm{min} / \mathrm{g}$ fresh callus) compared to calluses induced on Dicamba medium (respectively $0.554 ; 1.053 ; 0.009 ; 0.123 ; 774.31$ and 1432.76 $\mathrm{mmol} / \mathrm{min} / \mathrm{g}$ fresh callus). Otherwise, the highest activities were obtained in the calluses of 200 grays (4.034; 0.031 ; 1315.596; $2461.714 \mathrm{mmol} / \mathrm{min} / \mathrm{g}$ fresh callus) respectively for POD, PAL, catalase and ascorbate peroxidase.

That of PPOs ( $0.805 \mathrm{mmol} / \mathrm{min} / \mathrm{g}$ fresh callus) is observed in control calluses. As for the TAL, its activity is higher both in the calluses of 200 grays compared to the calluses of 300 grays $(0.145 \mathrm{mmol} / \mathrm{min} / \mathrm{g}$ fresh callus $)$. The weak enzymatic activities in the 2,4-D medium were obtained in the calluses of 300 grays for the PPO and the CAT $(0.777 ; 866.055$ 
$\mathrm{mmol} / \mathrm{min} / \mathrm{g}$ fresh callus). By cons, those of POD, PAL, TAL and APX (1.898; 0.022; 0.135 and $2248.286 \mathrm{mmol} / \mathrm{min} / \mathrm{g}$ fresh callus) are obtained in control calluses.

Table 3 Effect of auxin type on the catalase and peroxidase ascorbate in maize callus.

\begin{tabular}{llll}
\hline Dose & Type d'auxine & $\begin{array}{c}\text { Catalase } \\
\text { (mmol/min/g fresh callus) }\end{array}$ & $\begin{array}{c}\text { Peroxidase } \\
\text { (mmol/min/g fresh callus) }\end{array}$ \\
\hline Control & $2,4-\mathrm{D}$ & $1244,037 \pm 10,47^{\mathrm{a}}$ & $2248,286 \pm 19,14^{\mathrm{a}}$ \\
& Dicamba & $735,780 \pm 3,02^{\mathrm{b}}$ & $2014,286 \pm 10,78^{\mathrm{b}}$ \\
& $2,4-\mathrm{D}$ & $1315,596 \pm 4,33^{\mathrm{a}}$ & $2461,714 \pm 16,87^{\mathrm{a}}$ \\
200 grays & Dicamba & $849,541 \pm 5,67^{\mathrm{b}}$ & $1366,286 \pm 23,56^{\mathrm{b}}$ \\
& $2,4-\mathrm{D}$ & $866,055 \pm 4,85^{\mathrm{a}}$ & $2328,857 \pm 16,09^{\mathrm{a}}$ \\
300 grays & Dicamba & $737,614 \pm 3,60^{\mathrm{b}}$ & $917,714 \pm 26,22^{\mathrm{b}}$ \\
$\mathrm{P}$ & & 0.001 & 0.001 \\
$\mathrm{~F}$ & & 25,320 & 30.214 \\
\hline
\end{tabular}

\subsection{Correlation between quantitative variables}

To establish possible relationships between the different parameters measured during this study, a correlation matrix was realized (Table IV). Matrix analysis showed that the phenolic compounds (Pheno. C) exhibited a weak positive correlation ( $\mathrm{r}=0.48$ ) with polyphenoloxidase (PPO) and an average positive correlation $(\mathrm{r}=0.58)$ with tyrosine ammonia lyase (TAL). Furthermore, no correlation has been revealed between phenolic compounds and the other quantitative variables, namely, peroxidase (POD), phenylalanine ammonia lyase (PAL), catalase (CAT) and ascorbate peroxidase (APX). In contrary phenolic compounds, the matrix showed a strong positive correlation between PPO and the other enzymes studied which are, POD $(r=0.74)$, PAL $(r=0.87)$, TAL $(r=0,81)$, CAT $(r=0.81)$ and APX $(r=0.80)$. POD has a strong positive correlation with PAL $(r=0.82)$, TAL $(r=0.88)$ and CAT $(r=0.75)$ and a positive mean correlation $(r=0.62)$ with the APX. PAL activity is strongly correlated with that of TAL $(r=0.76)$, CAT $(r=0.79)$ and APX $(r=0.78)$. The TAL is moderately correlated $(r=0.65)$ with CAT and strongly correlated $(r=0.73)$ with APX. As for the CAT, it revealed an average positive correlation $(r=0.64)$ with APX.

Table 4 Correlation between quantitative variables

\begin{tabular}{|c|c|c|c|c|c|c|c|}
\hline & Pheno. C & PPO & POD & PAL & TAL & CAT & APX \\
\hline Pheno. C & & 0,48 & 0,36 & 0,40 & 0,58 & $-0,03$ & 0,36 \\
\hline PPO & & & 0,74 & 0,87 & 0,81 & 0,81 & 0,80 \\
\hline POD & & & & 0,82 & 0,88 & 0,75 & 0,62 \\
\hline PAL & & & & & 0,76 & 0,79 & 0,78 \\
\hline TAL & & & & & & 0,65 & 0,73 \\
\hline CAT & & & & & & & 0,64 \\
\hline
\end{tabular}

\section{APX}

Pheno. C ( $\mu \mathrm{g} / \mathrm{g}$ fresh callus): Phenolic compounds; PPO (mmol/min/g fresh callus): Polyphenoloxidase; POD (mmol/min/g fresh callus): Peroxidase; PAL (mmol/min/g fresh callus): Phenylalanine- ammonia-lyase (PAL) TAL (mmol/min/g fresh callus): Tyrosine ammonia-lyase; CAT (mmol/min/g fresh callus): Catalase; APX ( $\mathrm{mmol} / \mathrm{min} / \mathrm{g}$ fresh callus): Ascorbate peroxidase 


\section{Discussion}

The work submitted to our study focused on the evaluation of the effect of auxin type on the phenolic compounds synthesis and some enzymatic proteins activities in maize calluses whose seeds have been subjected to gamma radiation. So, several assays were carried out in order to determine the content of phenolic compounds, Phenylalanineammonia-lyase (PAL), tyrosine ammonia-lyase (TAL), Polyphenoloxidase (PPO), peroxidase (POD), Catalase (CAT) and Ascorbate Peroxidase (APX) in calluses.

The results showed that the auxin type has a very highly significant effect on the phenolic content of maize calluses. Indeed, 2,4-D makes it possible to produce more phenolic compounds in calluses compared to Dicamba. Our results are similar to those of [22] who found that liquid treatments supplemented with 2,4-D had a higher amount of anthocyanin than those supplemented with AIA in carrot callus [21] reported that increasing the concentration of 2,4-D upon initiation of somatic carrot petiole embryos caused an increase in the amounts of polyphenols. [7] also applied 2,4-D to determine the accumulation of anthocyanins in the cell culture of strawberries. 2,4-D appears to cause stress in plants and to increase the phenolic compounds synthesis $[31,12]$ also reported that the medium supplemented with 2,4-D for the carrot callus initiation showed an increase in abscissic acid which resulted in a higher synthesis of anthocyanins. Recently, [34] reported that salicylic acid such as 2,4-D significantly increased the content of phenolic compounds in the calluses of Garcinia brasiliensis. However, according to [26] the highest level of phenolic compounds was found in the calluses of Leucojum aestivum initiated and multiplied on the medium supplemented with dicamba. According to [35] Phenols are secondary metabolic compounds present in vegetables and synthesized in the shikimic acid pathway. These compound present different chemical structures as well as different biological properties and can influence the texture of cellular structures.

Our results also revealed that the auxin type has a significant effect on the activity of the enzymatic proteins studied. Calluses induced on medium containing 2,4-D have an enzymatic activity in Phenylalanine-ammonia-lyase (PAL), tyrosine ammonia-lyase (TAL), Polyphenoloxidase (PPO), peroxidase (POD), Catalase (CAT) and Ascorbate Peroxidase (APX) higher than those induced on medium containing Dicamba. Similar results have been reported by [6] who, working on mature and immature explants, showed that PPO and POD activities differed in the calluses obtained from the two explants types. According to [25], the activity of Superoxide dismutase (SOD) and CAT was strongly stimulated by paraquat, while dicamba and 2,4-D were effective only at higher concentrations in calluses potato. Treatment with Dicamba induced a less pronounced effect on the activity of CAT compared to 2,4-D. Cell metabolism and especially cell viability would be greatly compromised by the presence of 2,4-D. This may increase $\mathrm{H} 2 \mathrm{O} 2$ and CAT activities in cells [25]. [27] reported high levels of POD and PAL in Sesamum prostratum calluses with crude toxin from Fusarium oxysporumf. sp. In addition, [19] reported that the elicitor Magnaporthe grisea induced PPO and POD activities in the rice suspensions. According to these authors, POD increase in rice cells treated with the elicitor or the toxin may have involved an increased biosynthesis of lignin. PPO, POD and PAL activities increased significantly in injured and inoculated tubers. These results show that PAL, PPO and POD play a role in resistance to infection by soft rot of potatoes [24]. According to [9] PPO plays a more important role than POD in the enzymatic browning of Jatropha curcas calluses. In contrast, [10] found that PPO activity showed less browning during tissue culture. [3] reported that the browning rate was correlated with the total phenol content and PPO activity. This indicates that PPO and polyphenols have an impact on the browning of calluses in I. amethystoides. So, PAL would be the first enzyme in the phenolic metabolism route and has its enzymatic activity triggered by stress conditions. It catalyzes the L-phenylalanine (aromatic amino acid) desamination reaction in trans-cinnamic acid and free ammonia ions. This reaction is the first step of the broad range of reactions that biosynthesizes the phenylpropanoids[135 Furthermore, these same authors claimed that, the activity of the POD in the process of enzymatic browning has been questioned due to the low amount of hydrogen peroxide in the plant cells. However, it can have a synergistic effect on PPO and POD, due to hydrogen peroxide release in the oxidation of some phenolic composites, catalyzed for the PPO. So, Cell decompartimentalization involves a chain of events, including the activation of latent PPO or "de novo synthesis" of this enzyme, as well as the induction of POD.

\section{Conclusion}

The auxin type exerted a beneficial effect on the synthesis of the various parameters studied. Indeed, 2,4-D induces higher contents of phenolic compounds, Phenylalanine-ammonia-lyase (PAL), tyrosine ammonia-lyase (TAL), Polyphenoloxidase (PPO), peroxidase (POD), Catalase (CAT) and Ascorbate Peroxidase (APX) more than Dicamba in maize calluses. The calluses from the 200 grays dose contain more compound than the calluses from the control and from the 300 grays. 


\section{Compliance with ethical standards}

\section{Acknowledgments}

Our thanks go to Professor Tidou Abiba Sanogo, President of the Université Jean Lorougnon Guédé Daloa.

\section{Disclosure of conflict of interest}

Compliance with ethical standards Acknowledgments, disclosure of conflict of interest The authors do not disclose any conflict of interest.

\section{References}

[1] Akinyosoyea TS, Adetumbia AJ, Amusab DO, Olowolafea OM and OlasojiaaInstitute OJ. (2014). Effect of seed size on in vitro seed germination, seedlinggrowth, embryogenic callus induction and plantletregeneration from embryo of maize (Zea mays L.) seed. Nigerian Journal of Genetics, 28, 1-7.

[2] Burny Ph. (2011). Production et commerce mondiale en céréales en 2010 /2011: Livre blanc<<céréales>> ULg Gembloux Agro-bio tech et CRA-W Gembloux, 12.

[3] Cen Z, Su J, Deng X and Xie Y. (2016). Study on total phenolic content and correlation between ppo activity and browning of Corydalis saxicolabunting callus. Crops, 1,149-153.

[4] CIDES. (1999). Micropropagation pour l'entreprise serricole. Cahier des références techniques, 44.

[5] Countrystat. (2013).

[6] Duan Y, Su Y, Chao E, Zhang G, Zhao F, Xue T, Sheng W, Teng J and Xue J. (2018). Callus-mediated plant regeneration in Isodon amethystoidesusing young seedling leaves as starting materialS. in Plant Cell Tissue and Organ Culture Plant Cell, Tissue and Organ Culture (PCTOC).

[7] Edahiro J, Nakamura M, Seki M and Fursaki SH. (2005). Enhanced Accumulation of Anthocyanin in Cultured Strawberry Cells by Repetitive Feeding of L-Phenylalanine into the Medium. Journal of Bioscience and Bioengineering, 99(1), 43-47.

[8] FAO. (2018). Food and agricultural organization of the united nations.

[9] Harold M and Tabo R. (2015). Les cultures céréalières: riz, maïs, millet, sorgho et Blé, Nourrir l'Afrique, 37.

[10] He Y, Guo X and Lu R. (2009). Changes in morphology and biochemical indices in browning callus derived from Jatropha curcas, hypoco-tyls. Plant cell tissue organ culture journal, 98(1), 11-17.

[11] Huang LC, Lee YL, Huang BL, Kuo CI and Shaw JF. (2002). High polyphe-nol oxidase activity and low titratable acidity in browning bamboo tissue culture. in vitro cellular \& developmental biology plant journal, 38(4), 358365.

[12] Jan S, Parween T, Siddiqi TO and Mahmooduzzafar. (2012). Enhancement in furanocoumarin content and phenylalanine ammonia lyase activity in developing seedlings of Psoralea corylifolia $\mathrm{L}$. in response to gamma irradiation of seeds, 51(3), 341-350.

[13] Jimenez VM and Bangerth F. (2001). Endogenous hormone levels in explants and in embryogenic and nonembryogenic culture of carrot. Physiologia Plantarum, 111, 389-395.

[14] Joshi R, Shukla A and Kumar P. (2010). Interactive effect of ga3 and polyamines on in vitrosomatic embryogenesis from immature embryos in maize (zea maysl.). Maydica, 55, 111-119.

[15] Kouakou C, Akanvou L, Konan Y and Mahyao A. (2010). Stratégies paysannes de maintien et de gestion de la biodiversité du maïs (Zea mays L.) dans le département de Katiola, Côte d'Ivoire. Journal of Applied Biosciences, $33,2100-2109$.

[16] Kouakou TH. (2009). Embryogenèse somatique chez le cotonnier (gossypium hirsutum l. (malvaceae)) : variation des composés phénoliques au cours de la callogenèse et de la culture des suspensions cellulaires. Thèse de doctorat d'état, UFR des Sciences de la Nature, Université d'Abobo-Adjamé, (Abidjan, Cote D'Ivoire), 152. 
[17] Kouakou TH. (2003). Contribution à l'étude de l'embryogenèse somatique chez le cotonnier (Gossypium hirsutum L.): Evolution de quelques paramètres biochimiques au cours de la callogénèse et de cultures de suspensions cellulaires. Thèse de doctorat 3è cycle. Université de Cocody, Abidjan, Côte d'Ivoire, 144.

[18] Lobell DB, Bänziger M, Magorokosho C and Vivek B. (2011). Nonlinear heat effects on African Maize as evidenced by historical yield trials. Nature Climate Change, 1, 42-45.

[19] Macheix JJ, Fleuriet A and Jay-Allemand C. (2005). Les composés phénoliques des végétaux: un exemple de métabolites secondaires d'importance économique. Presses Polytechniques et Universitaires Romandes (éditions), Paris, France, 192.

[20] Malathi S, Madhavan S, Rabindran R, Paranidharan V and Velazhahan R. (2014). Differential induction of peroxidase and polyphenol oxidase isozymes in suspension-cultured cells of blast resistant and susceptible genotypes of rice in response to treatment with Magnaporthe grisea elicitor and toxin. Archives of Phytopathology and Plant Protection, 47(20), 2524-2532.

[21] Manivannan A, Kaul J, Singode A and Dass S. (2010). Callus induction and regeneration of elite Indian maize Inbreds. African Journal of Biotechnology, 9(44), 7446-7452.

[22] Mashayekhi K. (2001). The protein synthesis spectrum during the induction phase of somatic embryogenesis in carrot (Daucus carota L.) cultures and the role of nitrogen forms for embryo development. A thesis of Doctor of Science in Agriculture. Justus Liebig University, Giessen, 95.

[23] Mousavizadeh JS, Mashayekhi K, Akbarpour V, Kalati H and Ghasemi Y. (2010). Effect of IAA and 2,4-D on somatic embryogenesis and pigments synthesis of carrot root secondary phloem. Australian Journal of Agricultural Engineering, 1(4), 126-131.

[24] Murahige T and Skoog F. (1962). A revised medium for rapid growth and bioassay with tobacco virus cultures. Physiology plant, 15: 473-497.

[25] Ngadze E, Icishahayo D, Coutinho TA and van der Waals JE. (2012). Role of Polyphenol Oxidase, Peroxidase, Phenylalanine Ammonia Lyase, Chlorogenic Acid, and Total Soluble Phenols in Resistance of Potatoes to Soft Rot. Plant Disease, 96(2), 186-192.

[26] Peixoto PF, Gomes-Laranjo J, Vicente AJ and Madeira CMV. (2008). Comparative effects of the herbicides dicamba, 2, 4-D and paraquat on non-green potato tuber calli. Journal of Plant Physiology.

[27] Ptak A, El Tahchy A, Skrzypek E, Wójtowicz T and Laurain-Mattar D. (2013). Infuence of auxins on somatic embryogenesis and alkaloid accumulation in Leucojum aestivum callus. Central European Journal of Biology, 8(6), 591-599.

[28] Rajab R, Rajan SS, Satheesh LS, Harish SR, Sunukumar SS, Sandeep BS, Mohan TCK and Murugan K. (2009). Hypersensitive response ofSesamum prostratum Retz. elicited by Fusarium oxysporumf. Sesame (Schelt.) Jacz Butler. Indian Journal of Experimental Biology, 47, 834-838.

[29] Regnier T. (1994). Composés phénoliques du blé dur (Triticumturgidum L. var durum); Variation au cours du développement et de la maturation du grain relation avec l'apparition de la moucheture. Thèse de sciences et technique de langue doc, base de la production végétale, Université. Montpellier II, France, 177.

[30] Santimone M. (1973). Mécanismes des réactions d'oxydation péroxydasique. Thèse d'Etat, Université d'AIX Marseille II. $\mathrm{N}^{\circ}$ AO. 8321, 2343.

[31] Schlenker W and Lobell DB. (2010). Robust negative impacts of climate change on African agriculture. Environmental Research Letters, 75.

[32] Shariatpanahi ME, Belogradova K, Hessamvaziri L, Heberle-Bors E and Touraev A. (2006). Efficient embryogenesis and regeneration in fresh-ly isolated and cultured wheat (Triticum aestivum L.) microspores without stress pretreatment. Plant Cell Reports, 25(12), 1294-1299.

[33] Shimada T and Otani M. (2007). Sweet Potato. Biotechnology in Agriculture and Forestry: 59 Transgenic Crops IV (ed. byE.C. Pua and M.R.Davey)@ Springer-Verlag Berlin Heidelberg, 337-353.

[34] Singh. (2000). Biochemistry of phenolic compounds. (ed). Academic press. London-New York.

[35] Teixeira GM, Carvalho M, Leite AM, Barbosa S, dos Santos RP and Santos RB. (2019). Effect of Salicylic Acid, 2,4D and 2i-P on the Production of Secondary Metabolites in Garcinia brasiliensis Mart. Callus. Brazilian Archives of Biology and Technology, 62, 1678-4324. 
[36] Vitti Maria Carolina Dario, Fabiana Fumi Sasaki, Patrícia Miguel, Ricardo Alfredo Kluge and Celso Luiz Moretti. (2011). Activity of Enzymes Associated with the Enzymatic Browning of Minimally processed Potatoes. Brazilian Archives of Biology and Technology, 54 (5), 983-990.

[37] Von arnold S, Sabala I, Bozhkov P, Dyachok J and Filonova L. (2002). Developmental pathways of somatic embryogenesis. Plant Cell Tissue and Organ Culture, 69(3), 233-249.

[38] Zhou Y, Dahier JM, Underhill SJR and Wills RBH. (2003). Enzymes associated with blackheart development in pineapple fruit. Food Chemistry, 80, 565-572.

\section{How to cite this article?}

Kanga AN, Ayolie K, Yapo SS, N'guessan AR, Kouakou TH and Kouadio YJ. (2020). Effect of auxin type on the total phenols synthesis and some enzymatic proteins activity in maize callus from seeds irradiated to gamma radiation. World Journal of Advanced Research and Reviews, 6(2), 111-119. 